\title{
Impact of enclosure management on soil properties and microbial biomass in a restored semi-arid rangeland, Kenya
}

\author{
Stephen M MUREITHI ${ }^{1,2^{*}}$, Ann VERDOODT ${ }^{1,3}$, Charles KK GACHENE ${ }^{2}$, Jesse T NJOKA ${ }^{2}$, \\ Vivian O WASONGA ${ }^{2}$, Stefaan De NEVE ${ }^{3}$, Elizabeth MEYERHOFF ${ }^{4}$, Eric Van RANST ${ }^{1}$ \\ ${ }^{1}$ Laboratory of Soil Science, Department of Geology and Soil Science, Ghent University, B-9000 Gent, Belgium; \\ ${ }^{2}$ Department of Land Resources Management and Agricultural Technology, University of Nairobi, 00625 Nairobi, Kenya; \\ ${ }^{3}$ Research Unit of Soil Degradation and Conservation, Department of Soil Management, Ghent University, B-9000 Gent, Belgium; \\ ${ }^{4}$ Rehabilitation of Arid Environments Trust, 1051 Nakuru, Kenya
}

\begin{abstract}
Rangeland degradation is a serious problem throughout sub-Saharan Africa and its restoration is a challenge for the management of arid and semi-arid areas. In Lake Baringo Basin of Kenya, communities and individual farmers are restoring indigenous vegetation inside enclosures in an effort to combat severe land degradation and address their livelihood problems. This study evaluated the impact of enclosure management on soil properties and microbial biomass, being key indicators of soil ecosystem health. Six reseeded communal enclosures using soil embankments as water-harvesting structures and strictly regulated access were selected, varying in age from 13 to 23 years. In six private enclosures, ranging from 3 to 17 years in age, individual farmers emulated the communal enclosure strategy and restored areas for their exclusive use. Significant decreases in bulk density, and increases in the soil organic carbon, total nitrogen and microbial biomass contents and stocks were found in the enclosures as compared with the degraded open rangeland. In the private enclosures, the impact of rehabilitation on the soil quality was variable, and soil quality was in general lower than that obtained under communal management. The significant increase of absolute stocks of carbon, nitrogen and microbial biomass compared to the degraded open rangeland indicates the potential for the restoration of soil quality through range rehabilitation. Over-sowing with indigenous legume fodder species could improve total nitrogen content in the soil and nutritional value of the pastures as well.
\end{abstract}

Keywords: rangeland degradation; enclosures; microbial biomass; rehabilitation; reseeding; soil quality; Kenya

Citation: Stephen M MUREITHI, Ann VERDOODT, Charles KK GACHENE, Jesse T NJOKA, Vivian O WASONGA, Stefaan De NEVE, Elizabeth MEYERHOFF, Eric Van RANST. 2014. Impact of enclosure management on soil properties and microbial biomass in a restored semi-arid rangeland, Kenya. Journal of Arid Land, 6(5): 561-570. doi: 10.1007/s40333-014-0065-x

In severely degraded semi-arid rangeland, withdrawal of livestock grazing is often not sufficient to initiate the autogenic recovery of vegetations (Kinyua et al., 2009; Opiyo et al., 2011). As degradation continues, the condition of the rangeland ecosystem declines and then becomes relatively stable and resilient beyond a certain threshold (Milton et al., 1994). Rehabilitation hence needs to focus on the improvement of the microclimate and seedbed, reduction of water and wind erosion, installation of water harvesting structures and reseeding (Kinyua et al., 2009; Opiyo et al., 2011). Successful restoration of vegetation cover improves soil water balance and soil fertility, reduces soil erosion and restores the soil biodiversity and ecosys tem services (De Baets et al., 2006; Descheemaecker et al., 2006; Tongway and Ludwig, 2011). This illustrates the linkages

\footnotetext{
*Corresponding author: Stephen M MUREITHI (E-mail: stemureithi@uonbi.ac.ke)

Received 2013-08-22; revised 2014-02-08; accepted 2014-03-03

(C) Xinjiang Institute of Ecology and Geography, Chinese Academy of Sciences, Science Press and Springer-Verlag Berlin Heidelberg 2014
} 
and feedback loops occurring between biotic and abiotic components of the rangeland ecosystem, capable of reversing land degradation (Perrow and Davy, 2002a, b; King and Hobbs, 2006).

The capacity of the physical environment to sustain reproducing populations, eliminate potential threats, and exert resilience to natural disturbances is related to important soil functions that have to be evaluated when measuring the impact of rehabilitation (SER, 2004). In practice, soil processes such as nutrient cycling and biological interactions are studied to measure the recovery of the soil and to evaluate the long-term functioning and resilience of the restored ecosystem (Ruiz-Jaen and Aide, 2005). Good measures of the rehabilitation success can be obtained when the evolution of these ecosystem attributes with time is compared to the evolution recorded in reference sites (SER, 2004; Ruiz-Jaen and Aide, 2005). However, most soil functions recover much more slowly than the biotic attributes such as vegetation structure and diversity, and consequently, they are only rarely measured (Ruiz-Jaen and Aide, 2005). Recent studies on soil-vegetation feedbacks in rangeland health focused on the relationship between enclosure age and its effectiveness in improving the soil physical, chemical and biological properties that are key indicators of soil quality (Mekuria and Aynekulu, 2011; Mekuria, 2013). Although the aforementioned studies focused on the natural re-vegetation of enclosed rangelands, other scientists have studied the impact of different rehabilitation techniques on the recovery of vegetation (Kinyua et al., 2009; Opiyo et al., 2011) and soil quality (Wu et al., 2010).

The Njemps Flats in the Lake Baringo Basin in Kenya is a semi-arid rangeland inhabited communally by the Il Chamus agro-pastoral community, whose main livelihood source is livestock keeping (Meyerhoff, 1991). Severe environmental degradation and habitat loss in the Lake Baringo Basin have been reported in literature since the 1930s (Little, 1996). Major causes of land degradation in the Njemps Flats include burgeoning human and livestock population pressure, land use changes, overgrazing and droughts. The Rehabilitation of Arid Environments (RAE) Trust was initiated in 1982 to rehabilitate the severely de- graded rangeland around Lake Baringo and the surrounding hills, helping address the socio-economic problems caused by land degradation (de Groot et al., 1992). RAE established large-scale communal enclosures using a participatory approach to serve as demonstrations for range rehabilitation. Establishment of communal enclosures entailed fencing and preparation of the seedbed by ripping along the contours using a tractor fitted with chisel tines, producing parallel micro-catchments. Water harvesting structures were installed by alternately closing these furrow-like micro-catchments, followed by broadcast-reseeding with a mixture of indigenous grass species. Main grass species used were Cenchrus ciliaris, Eragrostis superba and Entrepogon macrostachyus. Scattered indigenous drought-resistant trees, such as Acacia tortilis, were also planted. The utilisation through occasional grazing and other income generating activities (IGAs) was strictly regulated and controlled. The main IGAs included fattening steers for sale, grass seed harvesting, dry season grazing, bee-keeping, grass-cutting (for thatch or hay) and wood-cutting (for building or fencing posts and fuel wood). Such benefits and the rehabilitation success attained in the communal enclosures increasingly inspired many local inhabitants to establish private enclosures, giving exclusive access and user rights. The result was a mosaic of enclosures, differing with respect to the management type and years since establishment.

In view of the increasing adoption of rangeland enclosure and the pressure exerted on the remaining communal grazing areas in the Lake Baringo Basin, it is important to understand its effectiveness in restoring the functions of degraded rangeland ecosystems. Focusing on the soil physical, chemical and biological properties of communal and private enclosures and the open rangeland, this study aimed to assess the impacts of different enclosure management strategies in restoring the abiotic ecosystem functions following rehabilitation.

\section{Materials and methods}

\subsection{Study area and site selection}

The Njemps Flats $\left(0^{\circ} 15^{\prime}-1^{\circ} 45^{\prime} \mathrm{N}, 35^{\circ} 45^{\prime}-36^{\circ} 30^{\prime} \mathrm{E}\right)$ 
covers approximately $305 \mathrm{~km}^{2}$ and is one of the eleven range units in Baringo county of Kenya (Fig. 1). This flat to slightly undulating plain has an average altitude of $900 \mathrm{~m}$ asl and is surrounded by high hills, ridges and plateaus, having peaks over 2,300 $\mathrm{m}$ (Thom and Martin, 1983). The semi-arid lowland receives a total annual rainfall varying between 300 to $700 \mathrm{~mm}$ (Kipkorir, 2002) and is characterized by a bimodal rainfall distribution with two peaks in April and November. The temperature in Njemps Flats shows little variation throughout the year, with mean monthly temperatures ranging from $24^{\circ} \mathrm{C}$ to $26^{\circ} \mathrm{C}$ (Ekaya et al., 2001; Kipkorir, 2002). The dominant soils in the Njemps Flats, according to a reconnaissance soil survey (USDASCS/GoK, 1978), are well-drained silt loam to clay loam, Eutric and Calcaric Fluvisols (FAO, 2006a, b). They are developed on alluvium from various Tertiary and Quaternary volcanic rocks and on sediments from basic igneous rocks. The main vegetation types include Acacia woodland (80\%), permanent swamp and seasonally flooded grassland (15\%) and shrub grassland (5\%). Livestock production by the Il Chamus agro-pastoralist community is the dominant land use type. Availability of fresh water in the flat terrain and increasing human and livestock population pressure encourage overgrazing. At present, severe land degradation is exacerbated by highly erodible soils in combination with erratic rainfall, in addition to intensive grazing pressure that has led to large-scale disappearance of perennial grasses. Ground cover is almost non-existent particularly during the dry seasons and droughts. Encroachment by Prosopis juliflora in the communal rangeland has also become a great concern to both local communities and planners.

To assess and monitor the rehabilitation process, we systematically selected six communal and six private enclosures across the Njemps Flats for this study (Table 1). The selection criteria, i.e. similarity of terrain, soil and land use types, aimed at minimising variability in the abiotic determinants of rangeland vegetation composition and functioning, and hence productivity. The major differences in communal and private enclosures were in average size, type of fencing material, management and user rights (Table 1).

\subsection{Sampling design}

Within each enclosure, three 50-m transects were placed in a Z-shaped orientation, starting at least 5 and

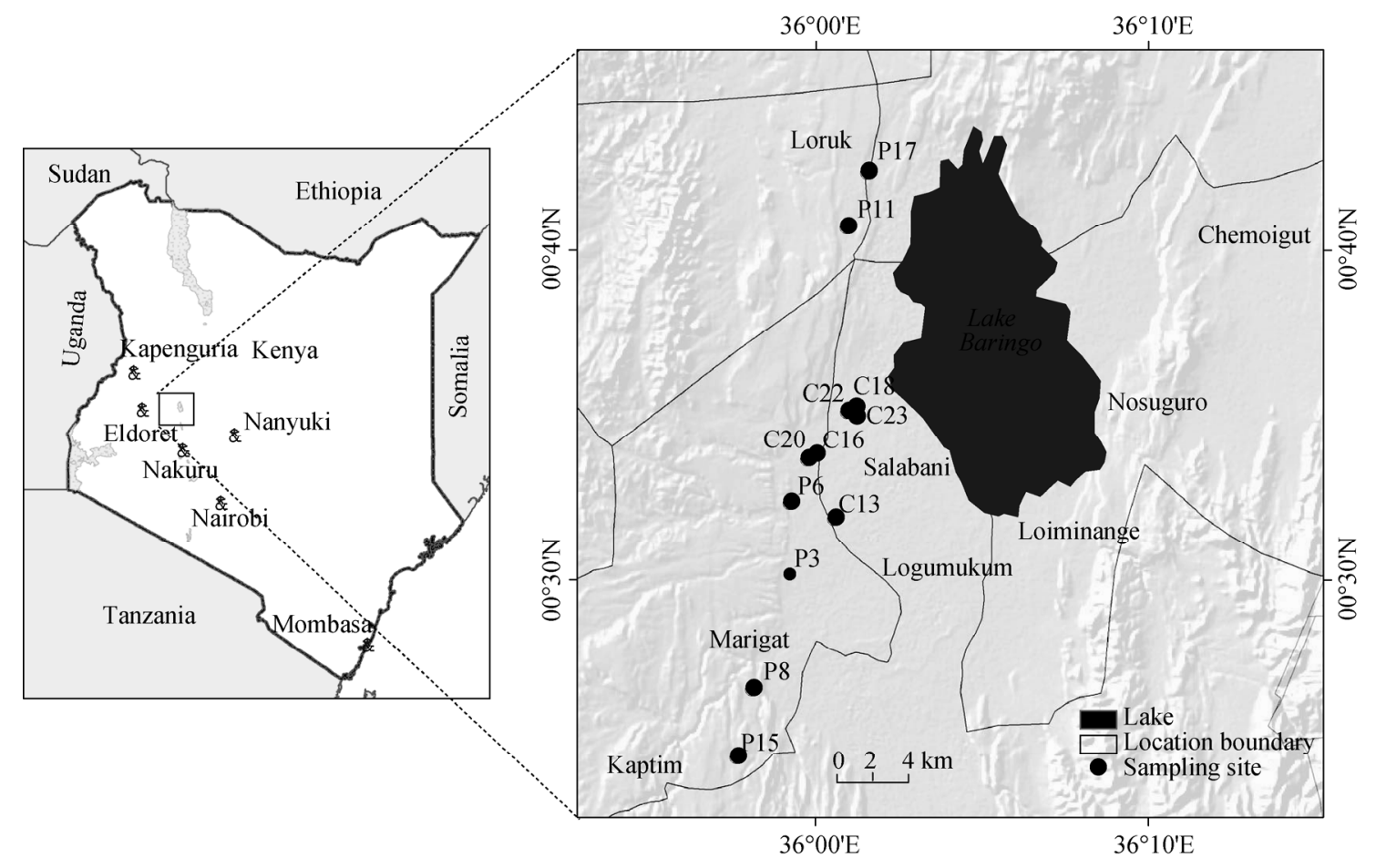

Fig. 1 Location of the Njemps Flats and study sites 
Table 1 General characterization of the selected enclosures

\begin{tabular}{clclll}
\hline ID & Management & Area $\left(\mathrm{hm}^{2}\right)$ & Age (a) & \multicolumn{1}{c}{ Utilization } & Fencing/User rights/Utilization frequency \\
\hline Co13 & Communal & 140.0 & 13 & G, GC, BK & \\
Co16 & Communal & 102.3 & 16 & G, GC & \\
Co18 & Communal & 16.7 & 18 & G, GC, BK, GS, WC & Fenced using solar-power; \\
shared but controlled user and access rights; & utilized occasionally \\
Co22 & Communal & 22.4 & 20 & G, GC & \\
Co23 & Communal & 6.6 & 22 & G, GC, BK, GS, WC & \\
$\operatorname{Pr} 3$ & Communal & 9.3 & 23 & G, GC, BK, GS, WC & \\
$\operatorname{Pr} 6$ & Private & 13.0 & 3 & G & Fenced using cut-thorn bush or live Opuntia \\
$\operatorname{Pr} 8$ & Private & 2.0 & 6 & G, GC & plants; \\
$\operatorname{Pr} 11$ & Private & 0.7 & 8 & G, GC, GS & Utilized frequently \\
$\operatorname{Pr} 15$ & Private & 1.0 & 11 & G, GC, BK & \\
$\operatorname{Pr} 17$ & Private & 2.5 & 15 & G, GC, BK & G, GC \\
\hline
\end{tabular}

Note: In the ID, "Co" refers to communal enclosures, "Pr" indicates private enclosures and the number represents the enclosure age. G, grazing; GC, grass cutting; GS, harvesting grass seed; BK, bee keeping; WC, wood cutting.

$30 \mathrm{~m}$ away from the boundaries of the private and communal enclosures respectively, to avoid edge effects. Along each transect, five $0.5-\mathrm{m}^{2}$ quadrats were laid $10 \mathrm{~m}$ apart and topsoil samples (upper $20 \mathrm{~cm}$ ) were collected at the centre of each quadrat. The five soil samples within each transect were mixed thoroughly to a 3-kg composite sample, producing a total of three composite samples collected from each enclosure. The soil characteristics outside the enclosures were determined using the same sampling design within a total of other 60 quadrats placed along twelve transect lines parallel to each enclosure, producing one composite sample for each transect.

About $0.5 \mathrm{~kg}$ sub-sample was immediately placed in air tight plastic bags for soil moisture determination. A 1-kg sub-sample was taken from each composite soil sample for biological analysis. These soil samples were sieved through a $2-\mathrm{mm}$ mesh to remove stones, roots, and large organic residues, and then sealed in plastic bags and stored at $4^{\circ} \mathrm{C}$. The remaining $2-\mathrm{kg}$ composite soil samples were air-dried, sieved through a 2-mm mesh and stored at room temperature for physical and chemical analyses. Steel cylinders of $98.2 \mathrm{~cm}^{2}$ were used to obtain undisturbed soil samples for soil bulk density determinations, using the same sampling design.

\subsection{Soil analyses}

The sand fraction $(>63 \mu \mathrm{m})$ was separated by wet sieving after destruction of organic matter and carbonates; the fine fraction $(<63 \mu \mathrm{m})$ was analyzed using the Robinson pipette method (Robinson, 1922). Soil bulk density was determined on the undisturbed soil samples according to the method described by Rhoades (1982). Total porosity was calculated using an estimated particle size density of $2.65 \mathrm{~g} / \mathrm{cm}^{3}$ for a general mineral soil. The moisture contents (MC) of the topsoil samples were determined by oven-drying a 10 -g subsample to constant weight at $105^{\circ} \mathrm{C}$. The calcimeter Bernard method (Nelson, 1982) was used to determine the calcium carbonate equivalent (CCE), defined as the total carbonates contained in $100 \mathrm{~g}$ of dry soil. Soil $\mathrm{pH}$ was measured in water using a 1:2.5 soil-solution ratio. Organic carbon content $\left(\mathrm{C}_{\text {org }}\right)$ for the topsoil (upper $20 \mathrm{~cm}$ ) was determined using the Walkley and Black method (Walkley and Black, 1934), while the Kjeldahl method (Bradstreet, 1965) was used to quantify the total nitrogen content $\left(\mathrm{N}_{\mathrm{t}}\right)$. The cation exchange capacity (CEC) and the basic cations $\mathrm{Ca}^{2+}, \mathrm{Mg}^{2+}, \mathrm{K}^{+}$and $\mathrm{Na}^{+}$were quantified using ammonium acetate buffered with $\mathrm{pH} 8.2$ (Anderson and Ingram, 1993), while the electrical conductivity (EC) was determined by measuring the electrical resistance of a 1:5 soil-water suspension. The exchangeable sodium percentage (ESP) was calculated as well. Microbial biomass $\mathrm{C}\left(\mathrm{C}_{\text {mic }}\right)$ and $\mathrm{N}\left(\mathrm{N}_{\text {mic }}\right)$ contents were determined by the chloroform fumigation-extraction method (Brookes et al., 1985; Anderson and Ingram, 1993) using 24-hour chloroform fumigation in a closed desiccator at $25^{\circ} \mathrm{C}$ and a $0.5 \mathrm{M}$ $\mathrm{K}_{2} \mathrm{SO}_{4}$ extracting solution. Correction factors of 0.45 were used to convert the measurements to $\mathrm{C}_{\mathrm{mic}}$ and 
$\mathrm{N}_{\text {mic }}$ (Jenkinson, 1988; Wu et al., 1990).

\subsection{Statistical analyses}

Statistical analysis were performed to test the impact of enclosure management on the restoration of the selected diagnostic soil physical, chemical and biological properties using one-way analysis of variance (ANOVA). Tukey's Honestly significant difference (HSD) test was used to detect differences between the treatment means at $P<0.05$. The differences in soil nutrient content and soil properties between the communal and private enclosures and the open rangeland were assessed respectively using a paired t-test. Pearson correlation coefficients were calculated to identify correlations among the selected soil characteristics. The enclosure management type was an independent variable in this study. All analyses were conducted using SPSS Version 16.0 (SPSS Inc., Chicago, Illinois, USA).

\section{Results}

\subsection{Soil texture, bulk density and moisture content}

The sand, silt and clay contents were similar in the open and enclosed rangeland under both management systems, though there was a non-significant trend towards higher silt and lower clay contents in the open rangeland (Table 2). The bulk density of topsoil at the time of sampling was significantly higher $(P<0.01)$ in the open rangeland than in the two types of enclosures. On average, the management of private and communal enclosures lowered the bulk density of topsoil from 1.57 and $1.48 \mathrm{~g} / \mathrm{cm}^{3}$ to 1.31 and $1.19 \mathrm{~g} / \mathrm{cm}^{3}$, respectively. The difference in bulk density between the communal and the private enclosures was also significantly lower. The average topsoil moisture content was $21 \%$ to $22 \%$ (w/w) within both enclosure management systems and $16 \%$ in the open rangeland.

\subsection{Soil chemical properties}

Contrary to significant differences reported in soil physical properties, the enclosure management system did not significantly alter topsoil $\mathrm{pH}$, total CCE, salinity and alkalinity (Table 3 ). There was a tendency (though not significant) towards higher ESP in the
Table 2 Soil physical properties of the private, communal enclosures and open rangeland

\begin{tabular}{cccccc}
\hline \multirow{2}{*}{ Soil properties } & \multicolumn{2}{c}{ Private } & & \multicolumn{2}{c}{ Communal } \\
\cline { 2 - 3 } \cline { 5 - 6 } & Open & Enclosed & & Open & Enclosed \\
\hline Sand (\%) & $9 \pm 7^{\mathrm{a}}$ & $12 \pm 5^{\mathrm{a}}$ & & $13 \pm 3^{\mathrm{a}}$ & $9 \pm 3^{\mathrm{a}}$ \\
Silt (\%) & $53 \pm 9^{\mathrm{a}}$ & $46 \pm 8^{\mathrm{a}}$ & & $59 \pm 5^{\mathrm{a}}$ & $56 \pm 8^{\mathrm{a}}$ \\
Clay (\%) & $38 \pm 9^{\mathrm{a}}$ & $42 \pm 12^{\mathrm{a}}$ & & $28 \pm 7^{\mathrm{a}}$ & $35 \pm 10^{\mathrm{a}}$ \\
Bulk density $\left(\mathrm{g} / \mathrm{cm}^{3}\right)$ & $1.57 \pm 0.10^{\mathrm{a}}$ & $1.31 \pm 0.07^{\mathrm{b}}$ & & $1.48 \pm 0.08^{\mathrm{a}}$ & $1.19 \pm 0.06^{6^{* *}}$ \\
Soil moisture (\%) & $16 \pm 2^{\mathrm{a}}$ & $21 \pm 2^{\mathrm{b}}$ & & $16 \pm 2^{\mathrm{a}}$ & $22 \pm 2^{\mathrm{b}^{* *}}$ \\
\hline
\end{tabular}

Note: Means along the same row with different letters indicate significant $\left(P<0.05\right.$, indicated by $\left.{ }^{*}\right)$ or highly significant $\left(P<0.01\right.$, indicated by $\left.{ }^{* *}\right)$ differences. Mean $\pm \mathrm{SD}, n=18$.

private than in the communal enclosures. This large variation was also noted in the exchangeable $\mathrm{Na}^{+}$ content (Table 3 ), providing more detailed information on the saturation of the exchange complex by the different basic cations. No significant differences were found in exchangeable cations recorded in the open and enclosed rangeland, except for the exchangeable $\mathrm{Mg}^{2+}$ content, which was significantly higher in the communal enclosures compared to the private enclosures and surrounding open rangeland.

Compared to the open rangeland, the enclosure treatment significantly increased the $\mathrm{C}_{\text {org }}$ and $\mathrm{N}_{\mathrm{t}}$ contents under both communal and private management, while $\mathrm{C}_{\text {org }}$ contents in the topsoil of the communal enclosures were significantly higher than in the private ones (Table 3). Average $\mathrm{C}_{\text {org }}$ contents in the soil of the open rangeland increased by $43 \%$ from 3.91 to $5.60 \mathrm{mg}$ $\mathrm{C} / \mathrm{g}$ soil in the private enclosures, and by $150 \%$ from 3.69 to $9.20 \mathrm{mg} \mathrm{C} / \mathrm{g}$ soil in the communal enclosures. The average $\mathrm{N}_{\mathrm{t}}$ contents were $0.41 \mathrm{mg} \mathrm{N} / \mathrm{g}$ soil in the open rangeland, increasing to 0.61 and $0.75 \mathrm{mg} \mathrm{N} / \mathrm{g}$ in the private and communal enclosures, respectively. The increase in $\mathrm{C}_{\text {org }}$ stocks in the private enclosures to 1,095 $\mathrm{g} \mathrm{C} / \mathrm{m}^{2}$ compared to the $925 \mathrm{~g} \mathrm{C} / \mathrm{m}^{2}$ measured in the surrounding open rangeland was insignificant. The average stocks in $\mathrm{N}_{\mathrm{t}}$ ranged from 96 to $119 \mathrm{~g} \mathrm{~N} / \mathrm{m}^{2}$ in the open and enclosed private rangeland, respectively. High supply of organic matter in the communal enclosures was sufficient to induce significant increases in both $\mathrm{C}_{\text {org }}$ and $\mathrm{N}_{\mathrm{t}}$ stocks. The $\mathrm{C}_{\text {org }}$ stocks doubled to $1,633 \mathrm{~g} \mathrm{C} / \mathrm{m}^{2}$ while the topsoil $\mathrm{N}_{\mathrm{t}}$ stocks reached $134 \mathrm{~g}$ $\mathrm{N} / \mathrm{m}^{2}$. The $\mathrm{C}: \mathrm{N}$ ratio did not change significantly. 
Table 3 Nutrient content, microbial biomass and acidification status of the private, communal enclosures and open rangeland

\begin{tabular}{|c|c|c|c|c|c|}
\hline \multirow{2}{*}{\multicolumn{2}{|c|}{ Index }} & \multicolumn{2}{|c|}{ Private } & \multicolumn{2}{|c|}{ Communal } \\
\hline & & Open & Enclosed & Open & Enclosed \\
\hline \multicolumn{2}{|l|}{$\mathrm{pH}$} & $8.2 \pm 0.9^{\mathrm{a}}$ & $8.4 \pm 0.3^{\mathrm{a}}$ & $8.4 \pm 0.4^{\mathrm{a}}$ & $8.3 \pm 0.2^{\mathrm{a}}$ \\
\hline $\mathrm{CCE}$ & $\%$ & $4.3 \pm 2.6^{\mathrm{a}}$ & $3.1 \pm 1.2^{\mathrm{a}}$ & $3.0 \pm 2.1^{\mathrm{a}}$ & $4.2 \pm 2.3^{\mathrm{a}}$ \\
\hline EC $1 / 5$ & $\mathrm{dS} / \mathrm{m}$ & $0.20 \pm 0.14^{\mathrm{a}}$ & $0.21 \pm 0.20^{\mathrm{a}}$ & $0.09 \pm 0.02^{\mathrm{a}}$ & $0.09 \pm 0.02^{\mathrm{a}}$ \\
\hline ESP & $\%$ & $6.2 \pm 11.2^{\mathrm{a}}$ & $3.6 \pm 3.7^{\mathrm{a}}$ & $0.7 \pm 0.7^{\mathrm{a}}$ & $0.3 \pm 0.3^{\mathrm{a}}$ \\
\hline CEC & $\mathrm{cmol}_{(+)} / \mathrm{kg}$ & $34.3 \pm 4.2^{\mathrm{a}}$ & $40.8 \pm 3.7^{\mathrm{b}}$ & $39.8 \pm 3.4^{\mathrm{a}}$ & $46.3 \pm 3.4^{\mathrm{b}^{*}}$ \\
\hline $\mathrm{Ca}^{2+}$ & $\mathrm{mg} / \mathrm{g}$ & $5.96 \pm 2.05^{\mathrm{a}}$ & $6.72 \pm 1.77^{\mathrm{a}}$ & $6.69 \pm 1.55^{\mathrm{a}}$ & $7.30 \pm 1.66^{\mathrm{a}}$ \\
\hline $\mathrm{Mg}^{2+}$ & $\mathrm{mg} / \mathrm{g}$ & $0.50 \pm 0.15^{\mathrm{a}}$ & $0.49 \pm 0.06^{\mathrm{a}}$ & $0.81 \pm 0.17^{\mathrm{b}}$ & $0.86 \pm 0.17^{\mathrm{b}^{*}}$ \\
\hline $\mathrm{K}^{+}$ & $\mathrm{mg} / \mathrm{g}$ & $0.62 \pm 0.24^{\mathrm{a}}$ & $0.61 \pm 0.19^{\mathrm{a}}$ & $0.51 \pm 0.08^{\mathrm{a}}$ & $0.70 \pm 0.26^{\mathrm{a}}$ \\
\hline $\mathrm{Na}^{+}$ & $\mathrm{mg} / \mathrm{g}$ & $0.50 \pm 0.89^{\mathrm{a}}$ & $0.34 \pm 0.33^{\mathrm{a}}$ & $0.06 \pm 0.06^{\mathrm{a}}$ & $0.03 \pm 0.02^{\mathrm{a}}$ \\
\hline \multirow{2}{*}{$\mathrm{C}_{\text {org }}$} & $\mathrm{mg} / \mathrm{g}$ & $3.91 \pm 1.30^{\mathrm{a}}$ & $5.60 \pm 1.44^{b}$ & $3.69 \pm 1.16^{\mathrm{a}}$ & $9.20 \pm 1.42^{\mathrm{c}^{* *}}$ \\
\hline & $\mathrm{g} / \mathrm{m}^{2}$ & $925 \pm 325^{\mathrm{a}}$ & $1,095 \pm 260^{\mathrm{a}}$ & $812 \pm 238^{\mathrm{a}}$ & $1,633 \pm 207^{\mathrm{b}^{* *}}$ \\
\hline \multirow{2}{*}{$\mathrm{N}_{\mathrm{t}}$} & $\mathrm{mg} / \mathrm{g}$ & $0.41 \pm 0.14^{\mathrm{a}}$ & $0.61 \pm 0.14^{\mathrm{b}}$ & $0.40 \pm 0.14^{\mathrm{a}}$ & $0.75 \pm 0.20^{\mathrm{b}^{* *}}$ \\
\hline & $\mathrm{g} / \mathrm{m}^{2}$ & $96 \pm 31^{\mathrm{a}}$ & $119 \pm 25^{\mathrm{ab}}$ & $89 \pm 28^{a}$ & $134 \pm 34^{\mathrm{b}^{*}}$ \\
\hline \multicolumn{2}{|l|}{$\mathrm{C}: \mathrm{N}$} & $10 \pm 3^{\mathrm{a}}$ & $9 \pm 2^{\mathrm{a}}$ & $9 \pm 2^{\mathrm{a}}$ & $13 \pm 5^{\mathrm{a}}$ \\
\hline \multirow{2}{*}{$\mathrm{C}_{\text {mic }}$} & $\mu \mathrm{g} / \mathrm{g}$ & $58.3 \pm 3.8^{\mathrm{a}}$ & $99.8 \pm 16.9^{b}$ & $57.5 \pm 2.7^{\mathrm{a}}$ & $137.8 \pm 10.8^{\mathrm{c}^{* *}}$ \\
\hline & $\mathrm{g} / \mathrm{m}^{2}$ & $13.7 \pm 1.1^{\mathrm{a}}$ & $19.5 \pm 2.4^{\mathrm{b}}$ & $12.7 \pm 0.6^{\mathrm{a}}$ & $24.5 \pm 1.3^{\mathrm{c}^{* *}}$ \\
\hline \multirow{2}{*}{$\mathrm{N}_{\text {mic }}$} & $\mu \mathrm{g} / \mathrm{g}$ & $28.7 \pm 2.2^{\mathrm{a}}$ & $39.5 \pm 9.2^{\mathrm{b}}$ & $30.0 \pm 1.7^{\mathrm{a}}$ & $61.7 \pm 6.6^{\mathrm{c}^{* *}}$ \\
\hline & $\mathrm{g} / \mathrm{m}^{2}$ & $6.8 \pm 0.8^{\mathrm{a}}$ & $7.7 \pm 1.3^{\mathrm{a}}$ & $6.7 \pm 0.5^{\mathrm{a}}$ & $11.0 \pm 0.9^{\mathrm{b}^{* *}}$ \\
\hline
\end{tabular}

Note: Means in the same row with different letters indicate significant $\left(P<0.05\right.$, indicated by $\left.{ }^{*}\right)$ or highly significant $\left(P<0.01\right.$, indicated by $\left.{ }^{* *}\right)$ differences. Mean \pm SD, $n=18$.

\subsection{Microbial biomass carbon and nitrogen}

The $\mathrm{C}_{\text {mic }}$ and $\mathrm{N}_{\text {mic }}$ were significantly and positively correlated to each other $(r=0.95)$ and to the $\mathrm{C}_{\text {org }}$ and $\mathrm{N}_{\mathrm{t}}$ contents with correlation coefficients $(r)$ of 0.74 and 0.92 , respectively. Topsoil bulk density was significantly and negatively correlated with the $\mathrm{C}_{\text {org }}(r=-0.79)$ and $\mathrm{N}_{\mathrm{t}}(r=-0.73)$ contents and the $\mathrm{C}_{\mathrm{mic}}(r=-0.90)$ and $\mathrm{N}_{\text {mic }}(r=-0.84)$ contents. Similar to $\mathrm{C}_{\text {org }}$ and $\mathrm{N}_{\mathrm{t}}$, both rangeland enclosure strategies significantly increased the $\mathrm{C}_{\text {mic }}$ and $\mathrm{N}_{\text {mic }}$ contents, with the highest contents measured in the communal enclosures (Table 3). Compared with the an average $\mathrm{C}_{\text {mic }}$ of $58 \mu \mathrm{g} \mathrm{C} / \mathrm{g}$ soil recorded in the open rangeland, the $\mathrm{C}_{\text {mic }}$ contents in the private and communal enclosures increased by $71 \%$ and $140 \%$, reaching average values of 99.8 and $137.8 \mu \mathrm{g} \mathrm{C} / \mathrm{g}$ soil, respectively. The $\mathrm{N}_{\text {mic }}$ contents were 1.4 and 2 times higher in the private (39.5 $\mu \mathrm{g} \mathrm{N} / \mathrm{g}$ soil) and communal (61.7 $\mu \mathrm{g} \mathrm{N} / \mathrm{g}$ soil) enclosures respectively than in the open rangeland (28.7-30.0 $\mu \mathrm{g} \mathrm{N} / \mathrm{g}$ soil).

\subsection{Chronosequence analysis of soil properties un- der different enclosure management systems}

Figures 2 to 4 illustrate the $\mathrm{C}_{\text {mic }}$ and $\mathrm{N}_{\text {mic }}$ stocks, $\mathrm{C}_{\text {org }}$ and $\mathrm{N}_{\mathrm{t}}$ stocks, and bulk density recorded within the different enclosures. Private enclosures Pr8 and Pr11 tended to approach the biological, chemical and physical fertility of the youngest communal enclosures. Private enclosure $\operatorname{Pr} 15$ however, was characterized by relatively high $\mathrm{C}_{\text {org }}\left(1,471 \mathrm{~g} \mathrm{C} / \mathrm{m}^{2}\right)$ and $\mathrm{N}_{\mathrm{t}}\left(159 \mathrm{~g} \mathrm{~N} / \mathrm{m}^{2}\right)$ stocks, but in contrast had relatively low $\mathrm{C}_{\text {mic }}(20.30 \mathrm{~g}$ $\left.\mathrm{C} / \mathrm{m}^{2}\right)$ and $\mathrm{N}_{\text {mic }}\left(20.30 \mathrm{~g} \mathrm{~N} / \mathrm{m}^{2}\right)$ stocks. The oldest private enclosure, $\operatorname{Pr} 17$, was below average with respect to both the microbial biomass $\left(19.24 \mathrm{~g} \mathrm{C} / \mathrm{m}^{2}, 6.89 \mathrm{~g}\right.$ $\left.\mathrm{N} / \mathrm{m}^{2}\right)$ and the $\mathrm{C}_{\text {org }}\left(1,029 \mathrm{~g} \mathrm{C} / \mathrm{m}^{2}\right)$ and $\mathrm{N}_{\mathrm{t}}\left(85 \mathrm{~g} \mathrm{~N} / \mathrm{m}^{2}\right)$ stocks. Similarly, both private enclosures of $\operatorname{Pr} 15$ and $\operatorname{Pr} 17$ were more compacted than the private enclosures Pr8 and Pr11 with respect to topsoil bulk density. With bulk density values of about $1.22 \mathrm{mg} / \mathrm{m}^{3}$, these private enclosures had comparable physical soil fertility as recorded in the communal enclosures.

\section{Discussion}

The studied sites had alkaline silt loam, silty clay loam and silty clay topsoils with the average $\mathrm{pH}$ values of about 8.2 to 8.4 (Table 3). These high $\mathrm{pH}$ values were 

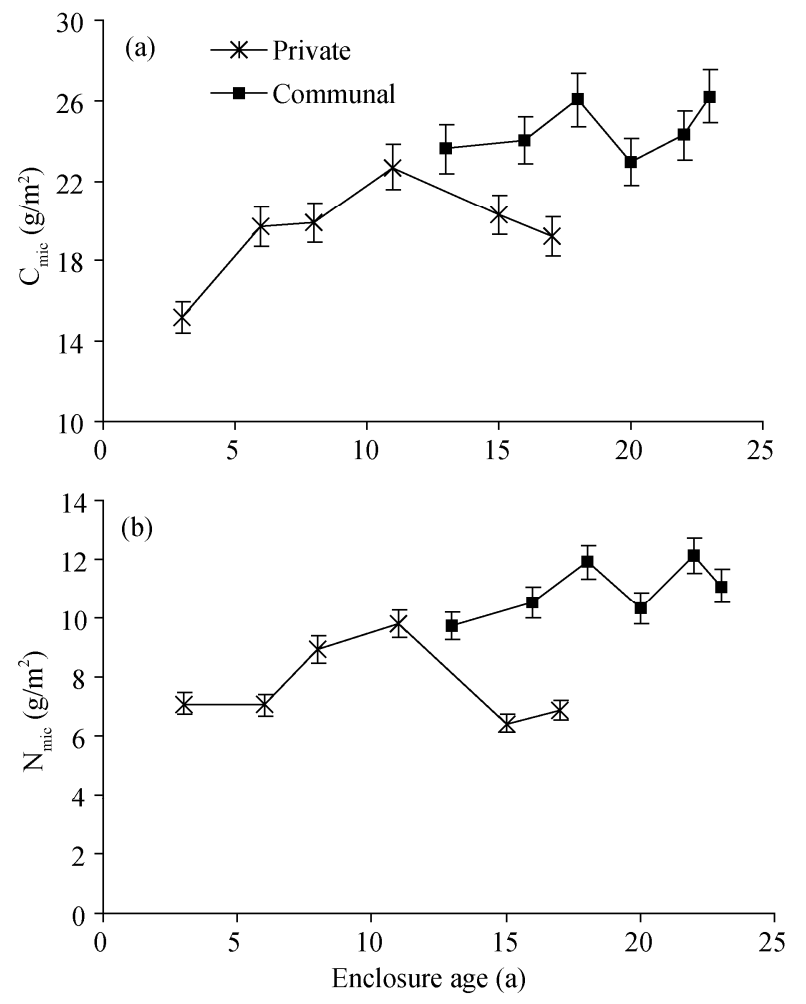

Fig. 2 Topsoil microbial $C$ and $\mathrm{N}$ stocks (mean $\pm \mathrm{SD}$ ) of the private and communal enclosures
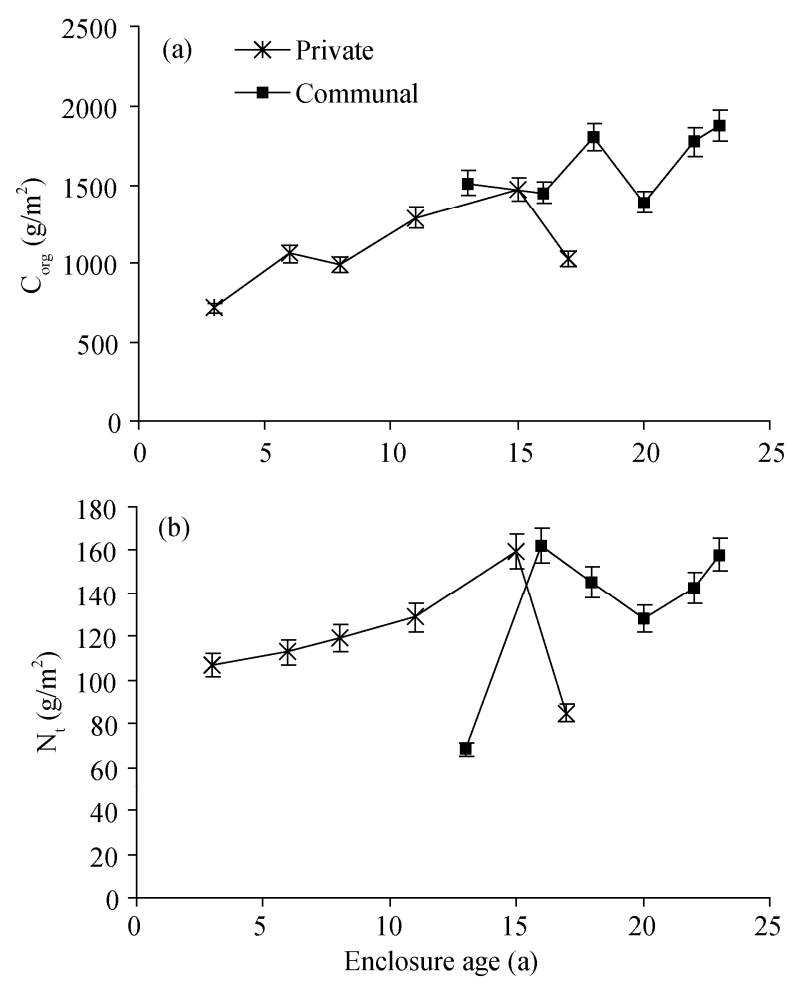

Fig. 3 Topsoil organic $\mathrm{C}$ and total $\mathrm{N}$ stocks (mean $\pm \mathrm{SD}$ ) of the private and communal enclosures

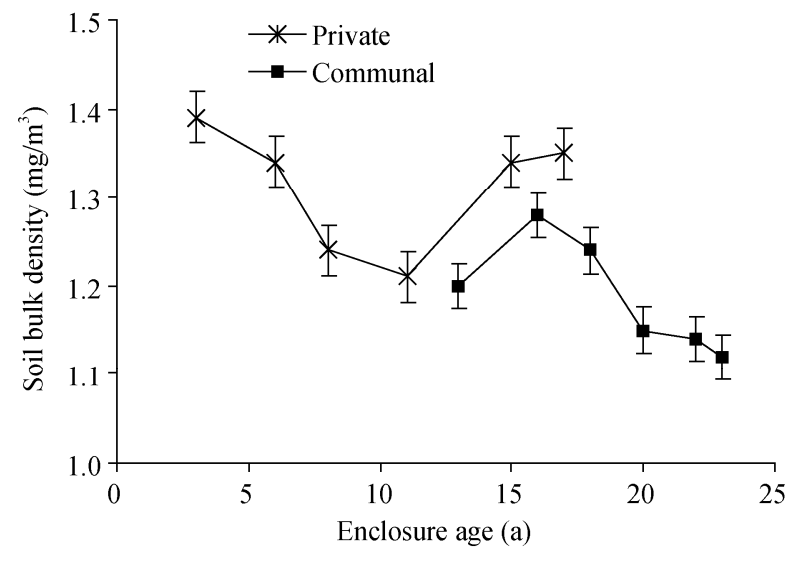

Fig. 4 Topsoil bulk density (mean $\pm S D$ ) of the private and communal enclosures

generally caused by the presence of free carbonates, ranging from $1 \%$ to $9 \%$ and with an average of about 3\%-4\% (Mureithi, 2006). Low EC values indicated the absence of significant amounts of highly soluble salts. As expected, $\mathrm{Ca}^{2+}$ dominated the exchange complex, followed by large amounts of $\mathrm{Mg}^{2+}, \mathrm{K}^{+}$and $\mathrm{Na}^{+}$. The high silt content and low topsoil organic matter content escalated the vulnerability of these soils to soil erosion and surface crusting (Lal, 2000a). According to Wasonga (2009), the effects of land-use on soil aggregate stability, surface run-off and soil loss in Njemps Flats enclosures manifested significantly lower run-off and erosion inside than outside the enclosures. Similar results were reported for enclosures in Tigray region of northern Ethiopia (Descheemaecker et al., 2006). Thus, besides ameliorating soil fertility, the recovery of vegetation reduces erosion hazard. In addition, topsoil bulk density in the open rangeland generally exceeded the root-restricting values of $1.45,1.50$ and $1.55 \mathrm{mg} / \mathrm{m}^{3}$ for silty clay, silty clay loam and silt loam textures, respectively (National Park Service, 2014). These unfavourable soil physical properties hamper critical soil functions, such as the capture, storage and supply of water, and the availability of roothold for plants (Kinyua et al., 2009; Opiyo et al., 2011).

Low $\mathrm{C}_{\text {mic }}, \mathrm{N}_{\text {mic }}, \mathrm{C}_{\text {org }}$ and $\mathrm{N}_{\mathrm{t}}$ contents were reported in the topsoil of the open rangeland (Table 3). According to Verdoodt et al. (2010), these open rangelands are characterized by both low vegetation cover and herbaceous biomass production, which negatively affect soil microbial population. The increase in vegetation cover inside the enclosures induced higher infiltration rates and reduced evaporative water losses (Wasonga et 
al., 2009), causing an increase in topsoil $\mathrm{MC}$ from $6 \%$ to $64 \%$ relative to the open rangeland. The ensuing conditions favoured microbial activity. The enclosures displayed varying degrees of soil quality recovery, which was illustrated by the variation in soil nutrient contents and properties. Though $\mathrm{C}_{\text {mic }}$ is considered as one of the most sensitive indicators of change in soil quality (Murage et al., 2000), only limited data are available in literature on its dynamics in restored tropical semi-arid rangelands. Our study showed that re-vegetation of degraded semi-arid rangeland within the enclosures resulted in significant $(P<0.01)$ increases in the $\mathrm{C}$ and $\mathrm{N}$ contents of microbial biomass, compared to the disturbed open grazing land (Table 3). Similar trends have been reported in studies focussing on ecosystem condition in comparison to a disturbed state. Chen et al. (2010) reported a significant increase in $\mathrm{C}_{\text {mic }}$ and $\mathrm{N}_{\text {mic }}$ in an old crop field abandoned for 10 years in the northeastern Tibetan Plateau in China. The $\mathrm{C}_{\text {mic }}$ and $\mathrm{N}_{\text {mic }}$ obtained in the old crop field were intermediate between those of an active crop field and grassland, illustrating a recovery following disturbance. Range rehabilitation promotes litter and organic matter supply by reducing soil disturbance, restoring herbaceous vegetation and increasing biomass production (Verdoodt et al., 2010; Mekuria and Aynekulu, 2011). Holt (1997) and Raiesi and Asadi (2006) reported a reduction in $\mathrm{C}_{\mathrm{mic}}$ under long-term grazing compared to adjacent ungrazed sites in Australia and Iran, respectively, whereas Moussa et al. (2007) found non-significant differences in $\mathrm{C}_{\text {mic }}$ between grazed and ungrazed plots in the semi-arid rangeland of South Africa. The microbial biomasses recorded in the restored rangeland in the Njemps Flats (73 to $156 \mu \mathrm{g} / \mathrm{g}$ soil) are relatively low compared to the literature data for the tropics. It is recognized however, that $\mathrm{C}_{\text {mic }}$ responds differently to changes in land uses. For example, Holt (1997) and Northup et al. (1999) reported that $\mathrm{C}_{\text {mic }}$ contents ranged from 160 to $326 \mu \mathrm{g} \mathrm{C} / \mathrm{g}$ under heavy and light grazing respectively in the sandy soils of semi-arid Queensland, Australia.

During restoration, the autogenic recovery of degraded rangelands generally results in very slow restoration of the chemical quality of soils (Kinyua et al., 2009). However, the reseeding and sustainable enclosure management strategies adopted in the Njemp Flats have evidently succeeded in significantly increasing both the microbial biomass and $\mathrm{C}_{\text {org }}$ and $\mathrm{N}_{\mathrm{t}}$ contents. The C:N ratios in the Njemps Flats suggested the presence of humified organic matter in the topsoil of the open rangeland and private enclosures, whereas the wider range of $\mathrm{C}: \mathrm{N}$ ratios recorded in the communal enclosures reflected a higher supply of decomposable organic matter. Although the original degradation state of the enclosed sites is not known, it is implicitly assumed that the enclosures and the adjacent open rangeland should have had comparable initial conditions at the time of enclosure establishment, such that changes in soil quality are a consequence of enclosure establishment and the respective management. Based on this assumption, it is acknowledged that the private enclosures have the potential to attain a similar soil quality as recorded in the communal enclosures, as illustrated by the results obtained in the private enclosures $\operatorname{Pr} 8$ and $\operatorname{Pr} 11$.

Enclosure age also plays a role in conditioning the rehabilitation impact on soil properties (Mekuria and Aynekulu, 2011). In Njemps Flats, the impact of enclosure age on the recovery of soil quality is variable (Figs. 2 and 3), perhaps due to the influence of management. The $\mathrm{N}_{t}$ content, though significantly higher inside the enclosures and with maximum values not exceeding $1 \mathrm{mg} \mathrm{N} / \mathrm{g}$ soil $\left(0.1 \% \mathrm{~N}_{\mathrm{t}}\right)$, is still low for a tropical grassland. Deficiency in $\mathrm{N}$ could severely limit the yield of grasses in managed arid and semi-arid rangelands (Ashrafa and McNeillyb, 1994). The recycling of $\mathrm{N}$ through animal droppings and urine during intermittent grazing is limited, resulting in an increasing $\mathrm{N}$ depletion in the soil. Considering that fertilization under the existing climatic and socioeconomic conditions is respectively inappropriate and unmanageable, oversowing with legume fodder species and indigenous trees (e.g. Acacia tortilis) adapted to the local semi-arid conditions to improve total soil nitrogen is a feasible option.

The herbaceous biomass production and cover are the catalyst of soil restoration (Mekuria et al., 2011), and were highly correlated with the $\mathrm{C}_{\text {org }}$ contents in this study, with correlation coefficients of 0.91 and 0.89 , respectively. A maximum value of $11.2 \mathrm{mg} \mathrm{C} / \mathrm{g}$ soil $\left(1.12 \% \mathrm{C}_{\mathrm{org}}\right)$ in the topsoil was recorded in the oldest sampled enclosure (23 years). This shows a slow but effective restora- 
tion of the organic carbon under the tropical semi-arid conditions, factored by the adopted enclosure management. In particular, the removal of organic matter from the enclosures by grazing and grass harvesting activities has the greatest influence on soil restoration. Since most of the tropical rangelands are on degraded soils, the potential for sequestering $\mathrm{C}$ through rangeland rehabilitation is substantial (FAO, 2001). Enhancing C stocks in degraded agricultural lands could have direct environmental, economic, and social benefits for local people (Lal, 2000b). Therefore, initiatives that sequester $\mathrm{C}$ are welcomed for the improvement in degraded soils, plant productivity and the consequent food safety and alleviation of poverty in dry land regions.

\section{Conclusions}

The results of this study showed that enclosures are effective in restoring the nutrient status and quality of degraded soils. Restoration of the soil quality in both the private and communal enclosures was rated successful when compared to the open grazing area. Clear trends with time could not be discriminated without reservation, partly due to the characteristics of the experimental set-up, possible modification by the enclosure management adopted, or the variation in soil chemical and biological properties in specific sites. Range rehabilitation under the private and communal enclosures resulted in higher microbial biomass, organic carbon and nitrogen stocks within less than 10 years of establishment compared to the degraded open rangeland. To improve the absolute soil $\mathrm{N}$ contents and stocks and pasture quality, enclosure management can consider incorporating indigenous fodder legume species and trees (e.g. Acacia tortilis) that have the potential to fix considerable amounts of N. Further research shall focus on seasonal dynamics of soil biological properties as well as long-term monitoring of the grazing and grass harvesting activities in order to understand their effects on the soil ecosystem in a semi-arid rangeland under restoration. Rehabilitation of degraded arid environments tackles the problems of land degradation, biodiversity loss, climate change and poverty simultaneously. Successful local actions can have a global impact and should therefore, be encouraged and supported.

\section{Acknowledgements}

This study was made possible through the financial support provided by the Flemish Interuniversity Council (VLIR) of Belgium in favour of the first author. We are grateful to the communal groups and private enclosure farmers who warmly welcomed us to their enclosures.

\section{References}

Anderson J M, Ingram J S I. 1993. Tropical Soil Biology and Fertility: A Handbook of Methods. Wallingford, Oxon, England: CAB International, 221.

Ashrafa M, McNeillyb T. 1994. Responses of three arid zone grasses to N deficiency: A greenhouse study. Arid Soil Research and Rehabilitation, 8: 125-136.

Bradstreet R B. 1965. The Kjeldahl Method for Organic Nitrogen. London: Academic Press.

Brookes P C, Landman A, Pruden G, et al. 1985. Chloroform fumigation and release of soil nitrogen; a rapid extraction method to measure microbial biomass nitrogen in soil. Soil Biology and Biochemistry, 17: 837-842.

Chen D D, Zhang S H, Dong S K, et al. 2010. Effect of land-use on soil nutrients and microbial biomass of an alpine region on the north-eastern Tibetan plateau, China. Land Degradation and Development, 21: 446-452.

De Baets S, Poesen J, Gyssels G, et al. 2006. Effects of grass roots on the erodibility of topsoils during concentrated flow erosion. Geomorphology, 76: 54-67.

de Groot P, Field-Juma A, Hall D O. 1992. Reclaiming the Land: Re-vegetation in Semi-arid Kenya. Nairobi: ACTS Press, 105.

Descheemaecker K, Nyssen J, Rossi J, et al. 2006. Sediment deposition and pedogenesis in exclosures in the Tigray highlands, Ethiopia. Geoderma, 132: 291-314.

Ekaya W N, Kinyamario J I, Karue C N. 2001. Abiotic and herbaceous vegetation characteristics of an arid rangeland in Kenya. African Journal of Range and Forage Science, 18: 1-8.

FAO. 2001. Soil Carbon Sequestration for Improved Land Management. Rome: World Soil Resources Report No. 96.

FAO. 2006a. FAO World Reference Base for Soil Resources. Rome: Food and Agriculture Organization of the United Nations, 128.

FAO. 2006b. FAO Guidelines for Soil Description ( $4^{\text {th }}$ ed.). Rome: Food and Agriculture Organization of the United Nations, 97.

Holt J A. 1997. Grazing pressure and soil carbon, microbial biomass and enzyme activities in semi-arid north-eastern Australia. Applied Soil Ecology, 5: 143-149.

Jenkinson D S. 1988. Determination of microbial biomass carbon and nitrogen in soil. In: Wilson J R. Advances in Nitrogen Cycling in Agricultural Ecosystems. Wallingford: $\mathrm{CAB}$ International, 368-386.

King E G, Hobbs R J. 2006. Identifying linkages among conceptual models of ecosystem degradation and restoration: towards an integrative framework. Restoration Ecology, 14: 369-378. 
Kinyua D, McGeoch L E, Georgiadis N, et al. 2009. Short-term and long-term effects of soil ripping, seeding, and fertilization on the restoration of a tropical rangeland. Restoration Ecology, 18: 226-233.

Kipkorir E C. 2002. Analysis of rainfall climate on Njemps Flats, Baringo District, Kenya. Journal of Arid Environments, 50: 445-458.

Lal R. 2000a. Physical management of soils of the Tropics: priorities for the $21^{\text {st }}$ Century. Soil Science, 165: 191-207.

Lal R. 2000b. World cropland soils as a source or sink for atmospheric carbon. Advances in Agronomy, 71: 145-191.

Little P D. 1996. Pastoralism, biodiversity and the shaping of savannah landscapes in East Africa. Journal of the International African Institute, 66: 37-51.

Mekuria W, Aynekulu E. 2011. Exclosure land management for restoration of the soils in degraded communal grazing lands in northern Ethiopia. Land Degradation and Development, 24: 528-538.

Mekuria W, Veldkamp E, Corre M D, et al. 2011. Restoration of ecosystem carbon stocks following exclosure establishment in communal grazing lands in Tigray, Ethiopia. Soil Science Society of America Journal, 75(1): 246-256.

Mekuria W. 2013. Conversion of communal grazing lands into exclosures restored soil properties in the semi-arid lowlands of Northern Ethiopia. Arid Land Research and Management, 27: 153-166.

Meyerhoff E. 1991. Taking Stock: Changing Livelihoods in a Agropastoral Community. Nairobi: African Centre for Technology Studies (ACTS) Press.

Milton S J, Dean W R J, du Plessis M A, et al. 1994. A conceptual model of arid rangeland degradation: the escalating cost of declining productivity. BioScience, 44: 70-76.

Moussa A S, Van Rensburg L, Kellner K, et al. 2007. Soil microbial biomass in semi-arid communal sandy rangelands in the western Bophirima district, South Africa. Applied Ecology and Environmental Research, 5: 43-56.

Murage E W, Karanja N K, Smithson P C, et al. 2000. Diagnostic indicators of soil quality productive and non-productive smallholders' fields of Kenya's Central Highlands. Agriculture, Ecosystems and Environment, 79: 1-8.

Mureithi S M. 2006. The effect of enclosures on rehabilitation of degraded semi-arid land in Lake Baringo Basin, Kenya. MSc. Thesis. Belgium: Ghent University.

National Park Service, U.S. Department of the Interior. 2014. Rangeland soil quality: soil compaction factsheet. [2014-01-28]. http://www. nature.nps.gov/geology/soils/Docs/Factsheet/Rangeland/Soil_Comp action.pdf.

Nelson R E. 1982. Carbonate and gypsum. In: Page A L, Millner RH, Keeney D R. Methods of Soil Analysis. Part 2. Chemical and Microbiological Properties. Madison: American Society of Agronomy and Soil Science Society of America, 181-197.

Northup B K, Brown J R, Holt J A. 1999. Grazing impacts on the spatial distribution of soil microbial biomass around tussock grasses in a tropical grassland. Applied Soil Ecology, 13: 259-270.

Opiyo F E O, Ekaya W N, Nyariki D M, et al. 2011. Seedbed preparation influence on morphometric characteristics of perennial grasses of a semi-arid rangeland in Kenya. African Journal of Plant Science, 5: 460-468.

Perrow M R, Davy A J. 2002a. Handbook of Ecological Restoration. Volume 1. Principles of Restoration. Cambridge: Cambridge University Press.

Perrow M R, Davy A J. 2002b. Handbook of Ecological Restoration. Volume 2. Restoration in Practice. Cambridge: Cambridge University Press.

Raiesi F, Asadi E. 2006. Soil microbial activity and litter turnover in native grazed and ungrazed rangelands in a semi-arid ecosystem. Biology and Fertility of Soils, 43: 76-82.

Rhoades J D. 1982. Methods of Soil Analysis. Part 2. Chemical and Microbiological Properties ( $2^{\text {nd }}$ ed.). Madison: American Society of Agronomy and Soil Science Society of America.

Robinson G W. 1922. A new method for the mechanical analysis of soils and other dispersions. Journal of Agricultural Science, 12: 306-321.

Ruiz-Jaen M C, Aide T M. 2005. Restoration success: how is it being measured? Restoration Ecology, 13: 569-577.

Society for Ecological Restoration (SER). 2004. The SER International Primer on Ecological Restoration. Tucson: Society for Ecological Restoration International [2012-03-10]. http://www.ser.org.

Thom D J, Martin N L, 1983. Ecology and production in Baringo-Kerio valley, Kenya. The Geographical Review, 73: 15-29.

Tongway D J, Ludwig J A. 2011. Restoring Disturbed Landscapes: Putting Principles into Practice (The Science and Practice of Ecological Restoration Series). Washington, DC: Island Press, 191.

USDA-SCS/GoK, 1978. Reconnaissance Soil Survey of Lake Baringo-Kerio Valley Area. Nairobi: Ministry of Agriculture Project Evaluation and Management Division, Government of Kenya.

Verdoodt A, Mureithi S M, Van Ranst E. 2010. Impacts of management and enclosure age on recovery of the herbaceous rangeland vegetation in semi-arid Kenya. Journal of Arid Environments, 74: 1066-1073.

Walkley A, Black I A. 1934. An examination of the Degtjareff method for determining organic carbon in soils: effect of variations in digestion conditions and of inorganic soil constituents. Soil Science, 63: $251-263$.

Wasonga V O. 2009. Linkages between land-use, land degradation and poverty in semi-arid rangelands of Kenya: the case of Baringo district. PhD Dissertation. Nairobi: University of Nairobi.

Wasonga V O, Nyariki D M, Ngugi R K. 2011. Assessing socio- ecological change dynamics using local knowledge in the semi-arid lowlands of Baringo, Kenya. Environmental Research Journal, 5: 11-17.

Wu J, Joergensen R G, Pommerening B, et al. 1990. Measurement of soil microbial biomass $\mathrm{C}$ by fumigation-extraction-an automated procedure. Soil Biology and Biochemistry, 22: 1167-1169. 